\title{
A PRELIMINARY STUDY OF THE MINERAL CHEMISTRY OF SELECTED ALBERTA KIMBERLITES
}

\author{
Steven Creighton ${ }^{1}$ and D. Roy Eccles ${ }^{1,2}$ \\ ${ }^{1}$ University of Alberta, Canada; ${ }^{2}$ Alberta Geological Survey, Canada
}

\section{INTRODUCTION}

Discovery of economic diamond deposits in kimberlites in the Northwest Territories rekindled interest in diamond exploration in northern Alberta. Thus far, 47 occurrences of kimberlites and rocks with kimberlitic affinities (for simplicity hereafter also called kimberlite) have been identified, 24 are diamondiferous. The kimberlite pipes range in areal extent from 1 to 74 ha and in overburden thickness from outcrop to $150 \mathrm{~m}$ deep.

Despite the high potential for a kimberlite occurrence with economic diamond grades in northern Alberta, few detailed studies have been conducted on these kimberlites. Therefore, the intent of this study is to provide a preliminary description of the mineral chemistry of five kimberlites K4B, K6, Phoenix, Kendu and Legend. K4B and K6 are from the Buffalo Head Hills kimberlite province and Phoenix, Kendu and Legend from the Birch Mountains kimberlite province. These kimberlites were selected to represent two major kimberlite provinces in northern Alberta in order to present inter- and intra-province variations in mineral chemistry.

\section{REGIONAL GEOLOGY}

\section{Buffalo Head Hills Kimberlite Province}

The Buffalo Head Hills kimberlite province is located in north-central Alberta within the confines of the Buffalo Head Terrane (BHT) and comprises 37 known kimberlites. The BHT is bounded in the north by the Great Slave Lake shear zone, towards the south, west and east it is bordered by the Wabamun, Chinchaga and Taltson domains respectively (Figure 1).

The major lithologies recovered from the BHT through drill core are mainly metaplutonic with minor metavolcanics and metasediments. U-Pb crystallization ages of the magmatic rocks range from 2324 to $1990 \mathrm{Ma}$. The ages oldest are from dioritic to granitic plutons that record a metamorphic age of $2017 \mathrm{Ma}$ determined from monazite and zircon geochronology (Ross and Eaton, 2002). A proposed model for the tectonics of the neighbouring Taltson Magmatic Zone (TMZ) involves the BHT being an older crustal block that has been reworked at $2.0 \mathrm{Ga}$ (Chacko et al., 2000).

The BHT is covered by up to $1600 \mathrm{~m}$ thick sedimentary sequences of Devonian and Cretaceous sediments. The sediments intruded by the kimberlites include Middle to Upper Devonian clastic, carbonate and evaporitic rocks
(Mossop and Shetsen, 1994). These sediments are in turn unconformably overlain by the Lower Cretaceous sandstones and shales of the Wabiskaw and Loon River Formations. Less common are Upper Cretaceous shales of the Shaftesbury and Dunvegan Formations, and the Smoky Group (Mossop and Shetsen, 1994). The Quaternary record consists of a complex jumble of till, glaciofluvial and glaciolacustrine sediments which may locally exceed $100 \mathrm{~m}$ in thickness resulting in varied levels of kimberlite exposure from outcrop to deeply buried (Creighton and Eccles, In Press). The Buffalo Head Hills kimberlites intrude the sedimentary rocks and, aside from those kimberlites that crop-out, are covered by the glacial sediments.

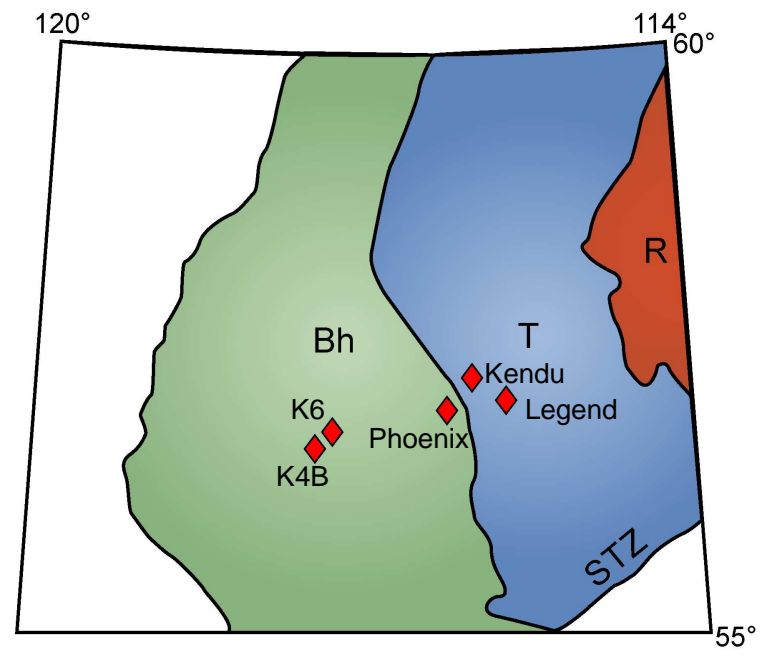

Figure 1. Basement map of northern Alberta, kimberlite locations are marked with diamonds. Bh: Buffalo Head Terrane, T: Taltson Magmatic Zone, R: Rae Province, STZ: Snowbird Tectonic Zone. The area surrounding is comprised of various Proterozoic terranes. (Modified after Pilkington et al., 2000)

\section{Birch Mountains Kimberlite Province}

The Birch Mountains kimberlite province comprises eight known kimberlites and is situated to the northeast of the Buffalo Head Hills kimberlite province in the TMZ. The TMZ is the southward extension of the $2500 \mathrm{~km}$ long, 2.0 Ga Thelon Terrane and is bounded by the Archean Churchill Province on the east and the Buffalo Head Terrane on the west (Hoffman, 1989; Figure 1). The TMZ is a belt of 1.99 to $1.95 \mathrm{Ga}$ dioritic to granitic plutons and 1.93 to $1.91 \mathrm{Ga}$ peraluminous granites (Bostock et al., 1987). The southern granitoids can be separated into an eastern group of biotite and biotite-hornblende granites and granodiorites and a 
western group of biotite and biotite \pm garnet \pm cordierite \pm spinel granites (Chacko et al., 2000). The kimberlites lie near the boundary between the TMZ and BHT - the diamondiferous Phoenix kimberlite actually lies within the BHT.

These basement rocks are covered by a succession of Phanerozoic sedimentary rocks similar to those overlying the Buffalo Head Terrane. The sedimentary cover in the vicinity of the kimberlites consists of mudstones and shales of the Upper Cretaceous Labiche Formation and Smoky Group unconformably overlaying Devonian clastics, carbonates and evaporites (Mossop and Shetsen, 1994). The kimberlites intrude into the sedimentary rocks and are covered with Quaternary glacial sediments similar to the those of the Buffalo Head Hills province but are typically more than $100 \mathrm{~m}$ thick (Creighton and Eccles, In Press).

\section{PHLOGOPITE CHEMISTRY}

With the exception of Kendu, phlogopite occurs in low modal abundance in the Alberta kimberlites. Preservation and crystal morphology differ greatly for each kimberlite; generally there is no correlation between grain size and morphology. None of the phlogopites identified in these samples display inverse pleochroism characteristic of micas containing tetrahedrally coordinated $\mathrm{Fe}^{3+}-$ that is, a tetraferriphlogopite component (Farmer and Boettcher, 1981).

K4B contains little phlogopite. The observed phlogopites from K4B are small $(0.05$ to $0.50 \mathrm{~mm})$ subhedral to anhedral groundmass or macrocrysts. The larger crystals are commonly embayed and corroded along the margins and altered along cleavage cracks. Although not common, some macrocrysts also enclose ilmenite microcrysts.

The K4B phlogopite population is distinctly bimodal with respect to Ti-content, divided into Ti-bearing and those containing no $\mathrm{Ti}$. Those that do contain $\mathrm{Ti}$, plot either in a field associated with kimberlite groundmass phlogopite, or in or near a field common to alkalic rocks in $\mathrm{Al}_{2} \mathrm{O}_{3}$ vs. $\mathrm{TiO}_{2}$ space (Figure 2A), as described by Mitchell (1995). The general evolution trend of the $\mathrm{K} 4 \mathrm{~B}$ phlogopites is a decrease in $\mathrm{Al}_{2} \mathrm{O}_{3}$ with increasing $\mathrm{Mg}$-number while the other major cations do not show any systematic change with increasing evolution.

The K6 kimberlite contains more phlogopite than K4B. Phlogopites in K6 are typically anhedral to subhedral groundmass micas. Some euhedral macrocrysts up to 0.5 $\mathrm{mm}$ are visible. The phlogopites are commonly corroded along the margins and are variably altered along cleavages. Phlogopites from the K6 kimberlite have tetrahedral cation ( $\mathrm{Si}$ and $\mathrm{Al}$ ) totals approximately equal to eight, indicating that these micas crystallized in an environment sufficiently rich in both $\mathrm{Si}$ and $\mathrm{Al}$ to fill the tetrahedral sites (Farmer and Boettcher, 1981). Additionally, there is no observed correlation between the tetrahedral cations and any major element suggesting that no substitution of other cations has occurred on the micas' tetrahedral sites. On the $\mathrm{Al}_{2} \mathrm{O}_{3}$ vs. $\mathrm{TiO}_{2}$ discrimination plot (Figure 2B), these phlogopites follow the trend observed from group 1 kimberlite decreasing Ti with increasing Al-content. These micas have increasing abundances of $\mathrm{Al}$ and $\mathrm{Cr}$ with increasing $\mathrm{Mg}$ number.

The Phoenix kimberlite contains a greater abundance of macrocrysts compared to microphenocrysts and groundmass phlogopite. The majority of phlogopites are euhedral and some contain inclusions of ilmenite, perovskite and/or chromite. The phlogopites from the Phoenix kimberlite are well preserved; the majority of micas do not show any alteration and have sharply defined, distinct margins.

Some of the phlogopites show a zoning relationship from $\mathrm{Fe}$ - and, relatively, Al-rich cores (approximately 2 and 2.8 cations per structural formula respectively) to $\mathrm{Fe}$ - and relatively Al-poor phlogopite mantles. These complexly mantled phlogopites may represent Fe-rich phlogopite xenocrysts that have been mantled by primary kimberlite phlogopite overgrowths. The Phoenix micas describe two compositional trends common to kimberlites. The first, and dominant trend, is the same as observed from the previous kimberlites - increasing Al-content at constant Ti. The second is commonly associated with tetraferriphlogopites from group 2 kimberlites (Mitchell, 1995) - decreasing Al at constant Ti (Figure 2C). This second trend is restricted to a few phlogopite grains and the presence of tetraferriphlogopite is not corroborated with petrographic observations of inverse pleochroism. Cr-abundance peaks at $\mathrm{Mg}$-number equal to 0.9; while at lower and higher values of $\mathrm{Mg}$-number $\mathrm{Cr}$ is below the detection limit.

While the other kimberlites have small modal abundances of phlogopite - or in the case of the Legend kimberlite, no phlogopite - Kendu contains approximately 50 volume percent phlogopite. This relatively high abundance of phlogopite gives Kendu superficial petrographic resemblance to group 2 kimberlites described from the Kaapvaal craton (Mitchell, 1995).

The phlogopites from Kendu widely vary in size and degree of alteration. Analyzed micas range from 0.02 to $>1.0 \mathrm{~mm}$ and the majority of phlogopite grains show at least some alteration along cleavage planes.

Figure 2D demonstrates that phlogopites from Kendu do not share a compositional evolution trend with any kimberlites. Indeed, on the Al vs. Ti discrimination plot these phlogopite compositions plot along a trend described from minettes and alnöites.

Similar to the Phoenix phlogopites, the Cr-content of Kendu micas increases with Mg-number and is also at the greatest abundance at $\mathrm{Mg}$-number of 0.9. These micas have a strong negative correlation between $\mathrm{Mg}$ and $\mathrm{Ti}$, and no positive correlation between $\mathrm{Fe}$ and $\mathrm{Ti}$, which may suggest that $\mathrm{Ti}$ is incorporated into the micas octahedral sites at the expense 

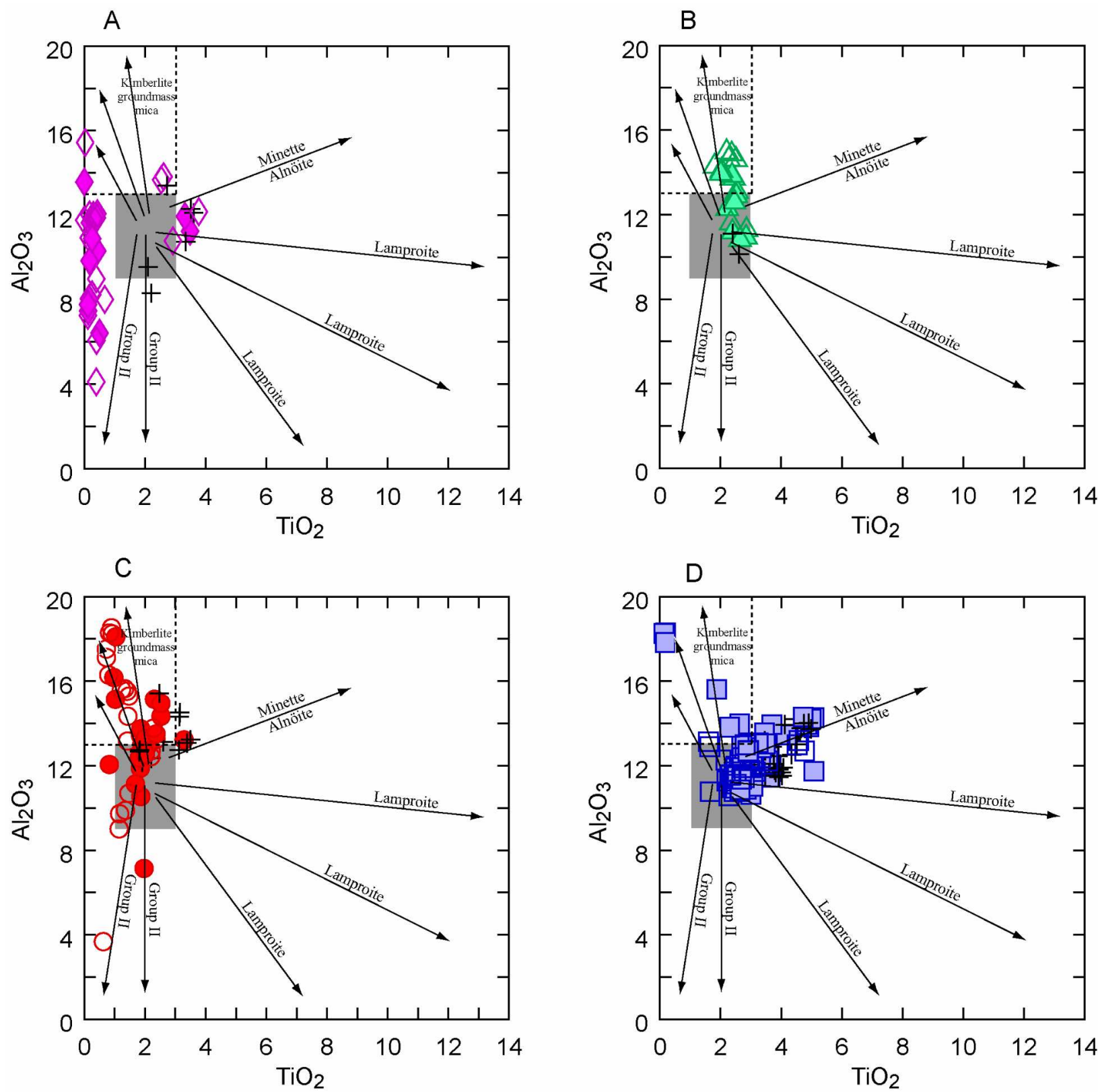

Figure 2. $\mathrm{Al}_{2} \mathrm{O}_{3}$ vs. $\mathrm{TiO}_{2}$ mica discrimination plots. The grey field indicates "primitive" phlogopite compositions common to alkalic rocks, the dashed field shows mica compositions typified by group 1 kimberlite groundmass phlogopites. Filled symbols represent analyses from phlogopite cores, open symbols are from rims and crosses represent analyses intermediate between core and rim. The fields and trends are from Mitchell (1995).

of $\mathrm{Mg}$. A possible mechanism for this substitution is described by the equation: $2 \mathrm{Mg}^{\mathrm{VI}} \leftrightarrow \mathrm{Ti}^{\mathrm{VI}}+[]^{\mathrm{VI}}$ (Forbes and Flower, 1974).

Samples from the Legend kimberlite do not contain phlogopite.

\section{SPINEL CHEMISTRY}

Haggerty (1975) observed that the Fe-content of kimberlite

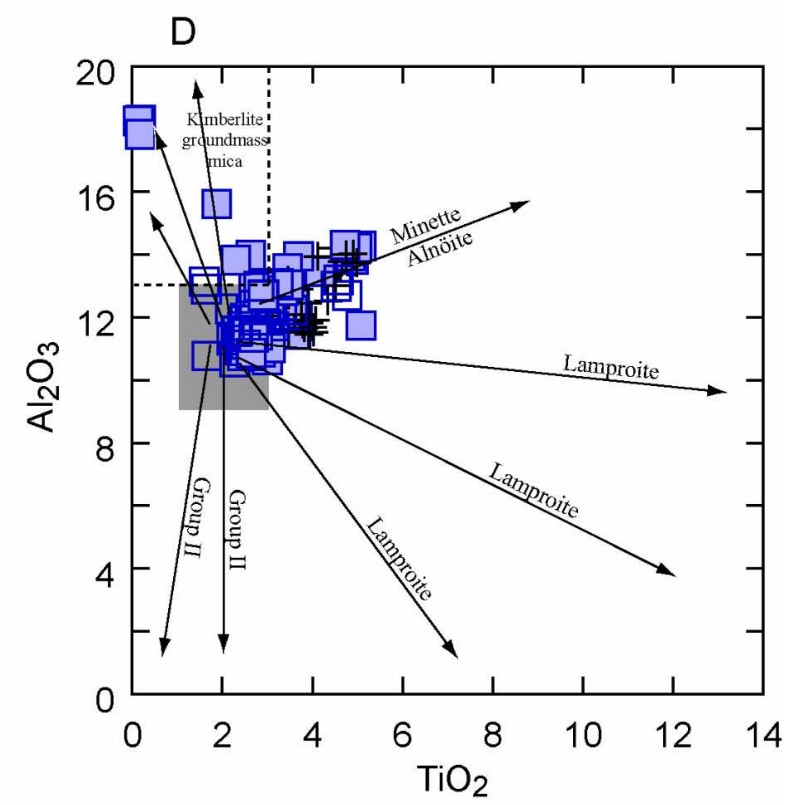

spinels increases with increasing degree of crystallization. Therefore, the ratio of $\mathrm{Fe}^{2+} /\left[\mathrm{Fe}^{2+}+\mathrm{Mg}\right]$ (FFM-ratio) is used as an index to indicate relative degree of differentiation. Ferric-ferrous iron ratios were calculated following the method of Droop (1987).

The analyzed spinels from K4B range in size from 0.01 to $0.10 \mathrm{~mm}$, typically, they are anhedral and commonly have $\mathrm{Fe}$-sulphides associated around the grain margins. Atoll textured spinels are rare. The majority of the spinels are aluminous magnesiochromites (AMC) with FFM-ratios ranging from 0.3 to 0.6. A single spinel analysis indicates a composition of magnesian ulvöspinel (MU). When these analyses are plotted in the reduced spinel prism, the AMC plot on the base of the prism and the MU plot near the apex. As such, these spinels roughly define the end-member compositions of magmatic trend 1 (Figure 3 A,B; magenta data points). 
The K6 spinels are typically small, ranging from 0.01 to $0.075 \mathrm{~mm}$. Grain morphology is not related to crystal size and there are equal proportions of rounded, anhedral and euhedral grains in any given size. Compositional zoning is infrequent as are atoll textured spinel. Spinels analyzed from the K6 kimberlite are compositionally similar to the spinels from K4B. The dominant spinel composition is AMC, plotting on the base of the reduced spinel prism (Figure 3 A,B; green data points). A few MU spinels plotting near the apex of the prism define magmatic trend 1 again with an absence of spinels of intermediate composition.

The grain size distribution of Phoenix spinels ranges from 0.04 to $0.30 \mathrm{~mm}$. These spinels are marked by the frequent occurrence of atoll texture. There is an apparent correlation between grain size and crystal morphology; the larger grains are commonly subhedral to anhedral, while the smaller crystals tend to be euhedral. Perovskite and Fe-sulphide inclusions are noted from a few of the spinels. Chemically the Phoenix spinels are dominantly MU although a few low-Cr AMC are observed in this population. There is a continuum of compositions evident in Figure 3C of decreasing $\mathrm{Al}-$ and increasing $\mathrm{Ti}-$ content with increasing degree of differentiation. These spinels group about the MU end of magmatic trend 1 .

The Legend spinels range from 0.015 to $0.15 \mathrm{~mm}$ and are dominantly single anhedral crystals but do occur in aggregates and intergrown twins. Spinels with atoll texture are rare. Compositionally, these spinels are similar to the Phoenix spinels - dominantly MU but the Legend spinels are not as highly evolved as the Phoenix spinels (Figure 3D).

Kendu spinels often are observed as components of larger spinel aggregates. These aggregates are commonly associated with $\mathrm{Fe}$-sulphides. Atoll textured spinels are atypical. The spinels range from 0.01 to $0.3 \mathrm{~mm}$, are commonly fractured and have embayed margins. Figure $3 \mathrm{E}$ exhibits the unique composition of the Kendu spinels with respect to the other kimberlites. Most of these spinels are highly differentiated and contain no appreciable amounts of $\mathrm{Cr}$ or $\mathrm{Al}$ such that they mostly plot near the ulvöspinel apex of the reduced spinel prism, although a few AMC are observed. Both $\mathrm{Fe}^{3+}$ and Ti increase rapidly with increasing differentiation indicating a high magnetite and/or titanomagnetite component in these spinels. The compositional trend of the Kendu spinels follows magmatic trend 2, progressing from AMC to ulvöspinel-magnetite and titanomagnetite with increasing degree of differentiation.

\section{OLIVINE CHEMISTRY}

The analyzed olivines are anhedral, commonly rounded, and mostly pseudomorphed by serpentine and/or secondary calcite. Indeed, olivine from Legend and Kendu do not appear sufficiently fresh for reliable microprobe analysis.
Analyses from K6 and Phoenix represent small remnants, mainly from the cores of larger grains.

$\mathrm{K} 4 \mathrm{~B}$ is anomalous with respect to the other Alberta kimberlites in that it contains approximately 90 volume percent olivine. The olivine crystals typically are very well preserved but they appear to be fractured fragments of larger grains. Their compositions range from $\mathrm{Fo}_{87}$ to $\mathrm{Fo}_{97}$ with a mean composition of $\mathrm{Fo}_{92}$.

K6 olivine has a tighter composition distribution ranging from $\mathrm{Fo}_{90}$ to $\mathrm{Fo}_{92}$. The Phoenix mean olivine composition is $\mathrm{Fo}_{90}$ but the distribution is wide with discrete olivine as low as $\mathrm{Fo}_{84}$ and as high as $\mathrm{Fo}_{94}$. Although the mean olivine compositions from the Alberta kimberlites are higher than the mean from kimberlites worldwide (Mitchell, 1995), they are still reasonable compositions for kimberlite olivine.

For all of the olivine analyzed, there is no observed correlation between major cation abundances and $\mathrm{Mg}$ number. Considering the poor preservation of the olivine and, except K4B, the lack of euhedral olivine in any of the kimberlites, the possibility exists that these olivines are mantle derived xenocrysts.

\section{DISCUSSION}

From the mineral chemistry of K4B, K6 and Legend, and the absence of minerals atypical of kimberlite, these rocks can be classified as genuine group 1 kimberlites. That the samples are taken from juvenile lapilli-bearing crater facies kimberlite does not seem to limit the usefulness of the mineral chemistry for classification of the rocks.

Kendu cannot be classified as a group 1 or group 2 kimberlite. The mineral chemistry of both the phlogopite and spinel are distinct from compositions observed in kimberlites (Mitchell, 1995).

Both K4B and Kendu are peculiar in their respective kimberlite provinces. The sample from K4B may represent an olivine crystal tuff. The phlogopite data suggest that Kendu may be a lamprophyre or a strongly hybridized kimberlite. Unfortunately, the spinel data do not offer any further constraints. The non-diamondiferous nature of Kendu may indicate that the magma was derived from a shallow lithospheric source. K4B and Kendu warrant more detailed investigation.

\section{ACKNOWLEDGEMENTS}

The authors would like to thank Sergei Matveev for his invaluable assistance with the electron microprobe, also Thomas Stachel for his valuable comments and reviews that have greatly improved the quality of this work. We would also like to acknowledge, and thank, Clinton Nielsen for producing a high-quality program for plotting spinel compositions in the spinel prism. 
Figure 3. Plots of spinel composition shown in the reduced spinel prism. Spinels from magmatic trend 1 are plotted as grey points and magmatic trend 2 as light blue points (Mitchell 1995). A, B: shows the K4B (magenta) and K6 (green), C: Phoenix, D: Legend, and E: Kendu.

\section{REFERENCES}

Bostock, H.H., van Breemen, O., and Loveridge, W.D., 1987. Proterozoic geochronology in the Taltson Magmatic Zone, NWT. In: Radiogenic Age and Isotopic Studies, Report 1. Geological Survey of Canada, Paper 87-2, pp. 73-80.

Chacko, T., De, S.K., Creaser, R.A., and Muehlenbachs, K., 2000. Tectonic setting of the Taltson magmatic zone at 1.9-2.0 Ga: a granitoid-based perspective. Canadian Journal of Earth Sciences, 37: 1597-1609.

Creighton, S. and Eccles, D.R., In Press. 2002 Compilation of Alberta Ultramafic Rock Occurrences: Location, Ground Geophysics, Drill Hole Logs and Diamond Content. Alberta Energy and Utilities Board, Alberta Geological Survey, Geo-Note 2002-23: Electronic Format (PDF).

Droop, G.T.R., 1987. A general equation for estimating $\mathrm{Fe}^{3+}$ concentrations in ferromagnesian silicates and oxides. Mineralogical Magazine, 51: 431-435.

Farmer, G.L. and Boettcher, A.L., 1981. Petrologic and crystalchemical significance of some deep-seated phlogopites. American Mineralogist, 66: 1154-1163.

Forbes, W.C. and Flower, M.F.J., 1974. Phase relations of titanphlogopite, $\mathrm{K}_{2} \mathrm{Mg}_{4} \mathrm{TiAl}_{2} \mathrm{Si}_{6} \mathrm{O}_{20}(\mathrm{OH})_{4}$ : A refractory phase in the upper mantle? Earth and Planetary Science Letters, 22: 60-66.

Haggerty, S.E., 1975. The Chemistry and Genesis of Opaque Minerals in Kimberlites. Physics and Chemistry of the Earth, 9: 295-307.

Hoffman, P.F., 1989. Precambrian geology and tectonic history of North America. In: The Geology of North America - An overview. Geological Society of America, Boulder, Colorado, pp. 447-512.

Mitchell, R.H., 1995. Kimberlites, Orangeites, and Related Rocks. Plenum Press, New York.

Mossop, G.D. and Shetsen, I. (Compilers). Geological Atlas of the Western Canada Sedimentary Basin. 1994. Calgary, AB, Canadian Society of Petroleum Geologists and Alberta Research Council. 510 p.

Pilkington, M., Miles, W.F., Ross, G.M., and Roest, W.R., 2000. Potential-field signatures of buried Precambrian basement in the Western Canada sedimentary basin. Canadian Journal of Earth Sciences, 37: 1453-1471.

Ross, G.M. and Eaton, D.W., 2002. Proterozoic Tectonic Accretion and Growth of Western Laurentia: Results From Lithoprobe Studies in Northern Alberta. Canadian Journal of Earth Sciences, 39: 313-329.

Steven Creighton, Dept. of Earth and Atmospheric Sciences, University of Alberta, Edmonton, AB, Canada T6G 2E3

Steven.Creighton@ualberta.ca
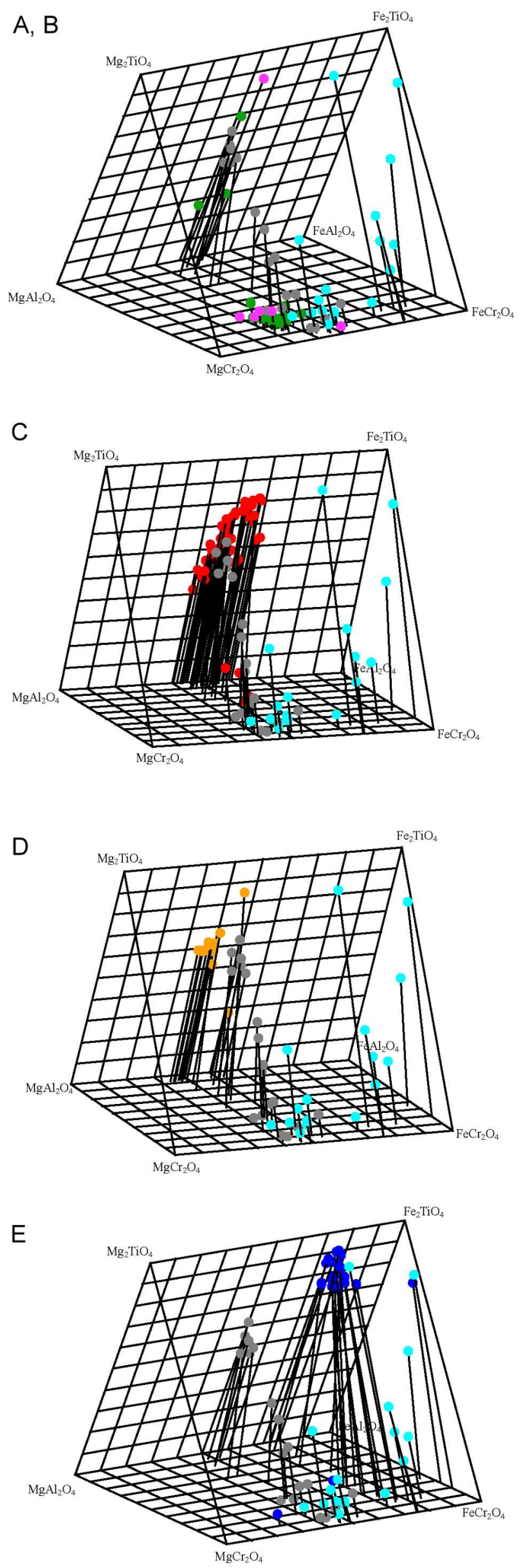